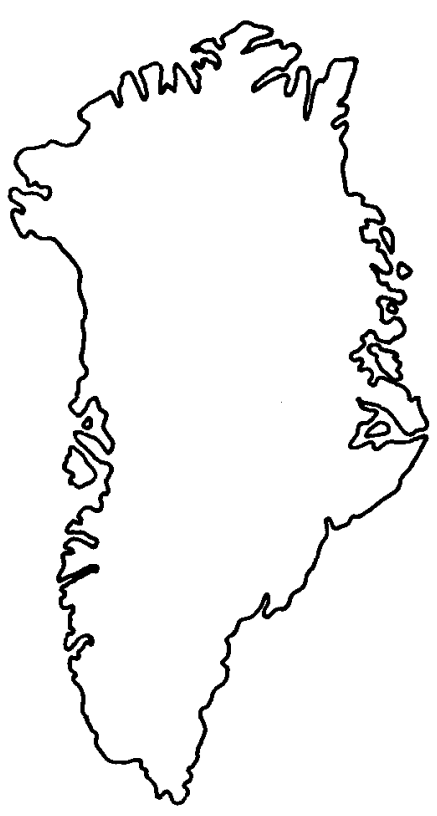

\title{
The small shelly fossil Mongolitubulus from the Lower Cambrian of central North Greenland
}

\author{
John S. Peel and Mark R. Blaker
}

The problematic small shelly fossil Mongolitubulus Missarzhevsky, 1977 is reported from the Henson Gletscher Formation of late Early Cambrian age (Bonnia-Olenellus Zone) in southern Freuchen Land, central North Greenland. Mongolitubulus is described from strata of similar Early Cambrian age (Botomian) in Mongolia and Kazakhstan, and is also reported from Antarctica. The Greenland Mongolitubulus is the first record of the genus from the North American continent.

J. S. P., Grønlands Geologiske Undersøgelse, Øster Voldgade 10, DK-1350 København K, Danmark.

M. R. B., Department of Geology, University of Keele, Staffs. ST5 $5 B G, U . K$.

In this preliminary paper we briefly report the occurrence of the problematic 'small shelly fossil' Mongolitubulus Missarzhevsky, 1977 from the Lower Cambrian Henson Gletscher Formation of southern Freuchen Land, central North Greenland (figs 1, 2).

The small (length 1-2 mm) and phosphatic fossil Mongolitubulus was first described by V. V. Missarzhevsky (1977) on the basis of four specimens from the Lower Cambrian of Mongolia, with $M$. squamifer Missarzhevsky, 1977 as type species. Missarzhevsky noted that the narrow, tubular fossils are characterised by a prominent scale-like ornamentation on the outer surface, consisting of densely-spaced, ovoid to diamond-shaped elements. Individual elements merge with the general surface of the tube at their abapical margin but are raised and slightly overhang the general surface at their adapical margin (adapical and abapical refer respectively to the narrower and wider ends of the slowly expanding tube).

Missarzhevsky \& Mambetov (1981) subsequently described Mongolitubulus squamifer from the Geress sub-unit of the Shabakty Series in Maly Karatau, Kazakhstan, illustrating a specimen with more irregular ornamentation than illustrated by Missarzhevsky (1977) in the holotype from Mongolia. Recently, Mongolitubulus has been reported, but neither illustrated nor described, from blocks of Lower Cambrian carbonates in glacio-marine sediments exposed in the Melville Peninsula, West Antarctica (Gazdzicki \& Wrona, 1986). 


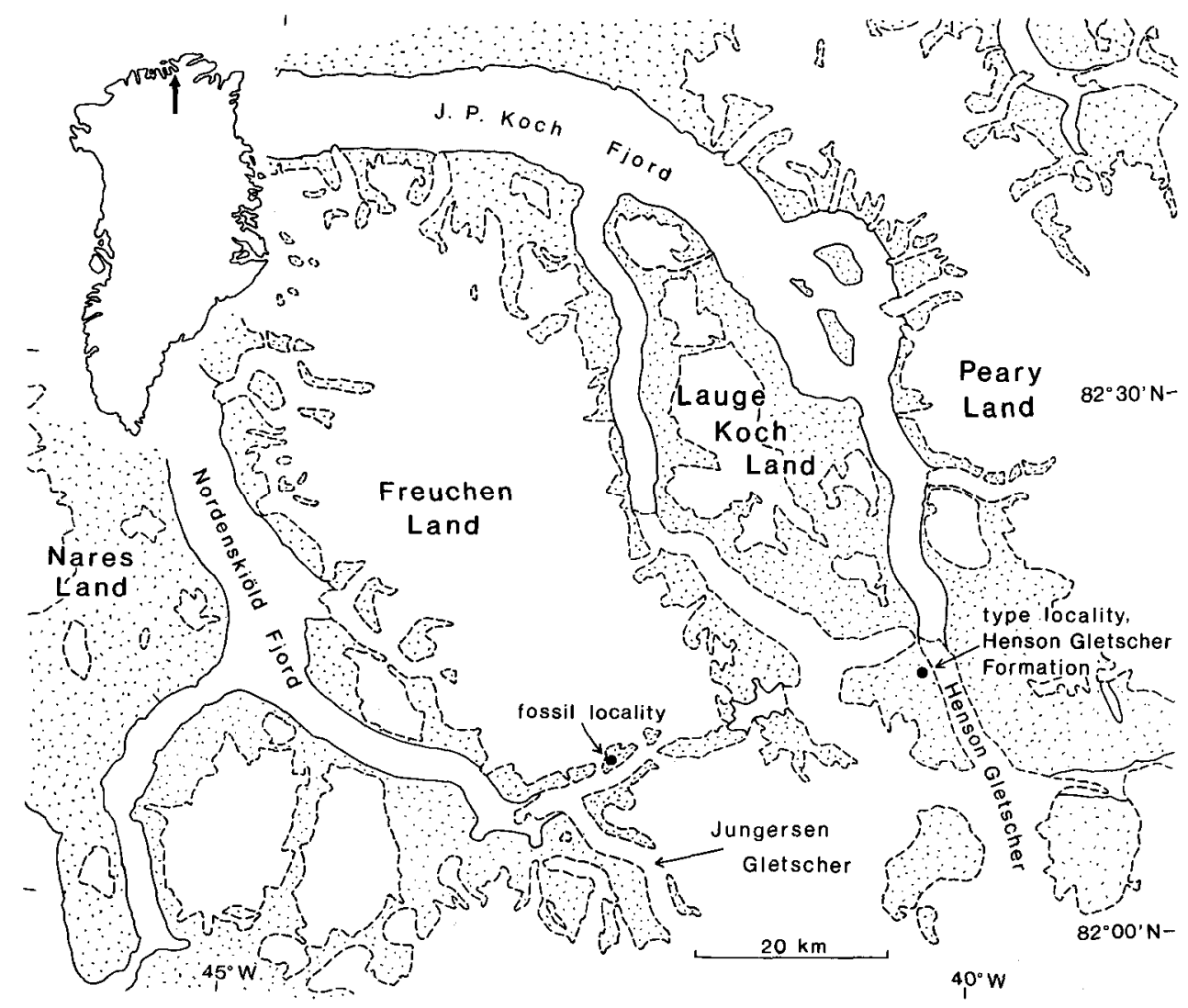

Fig. 1. The Freuchen Land region of central North Greenland showing the collection locality for Mongolitubulus squamifer Missarzhevsky, 1977 (GGU sample 301351). This is the same locality discussed by Blaker (1986).

\section{Mongolitubulus squamifer Missarzhevsky, 1977}

Fig. 2

Figured material. MGUH 18.288 and 18.289 from GGU sample 301351, Henson Gletcher Formation, southern Freuchen Land, central North Greenland.

Additional material. Common in GGU sample 301351; rare fragmentary specimens occur in several other samples from the Henson Gletscher Formation in the same region.

Discussion. The two figured specimens illustrate the degree of variation which exists in the surface ornamentation. The diamond-shaped elements in fig. 2A, B resemble those illustrated in the holotype (Missarzhevsky, 1977, pl. 1, figs 1,2) but are somewhat more closely juxtaposed and regularly arranged. The specimen illustrated by Missarzhevsky \& Mambetov (1981, pl. 14, figs 1,2) from Maly Karatau shows ornamentation similar to that 


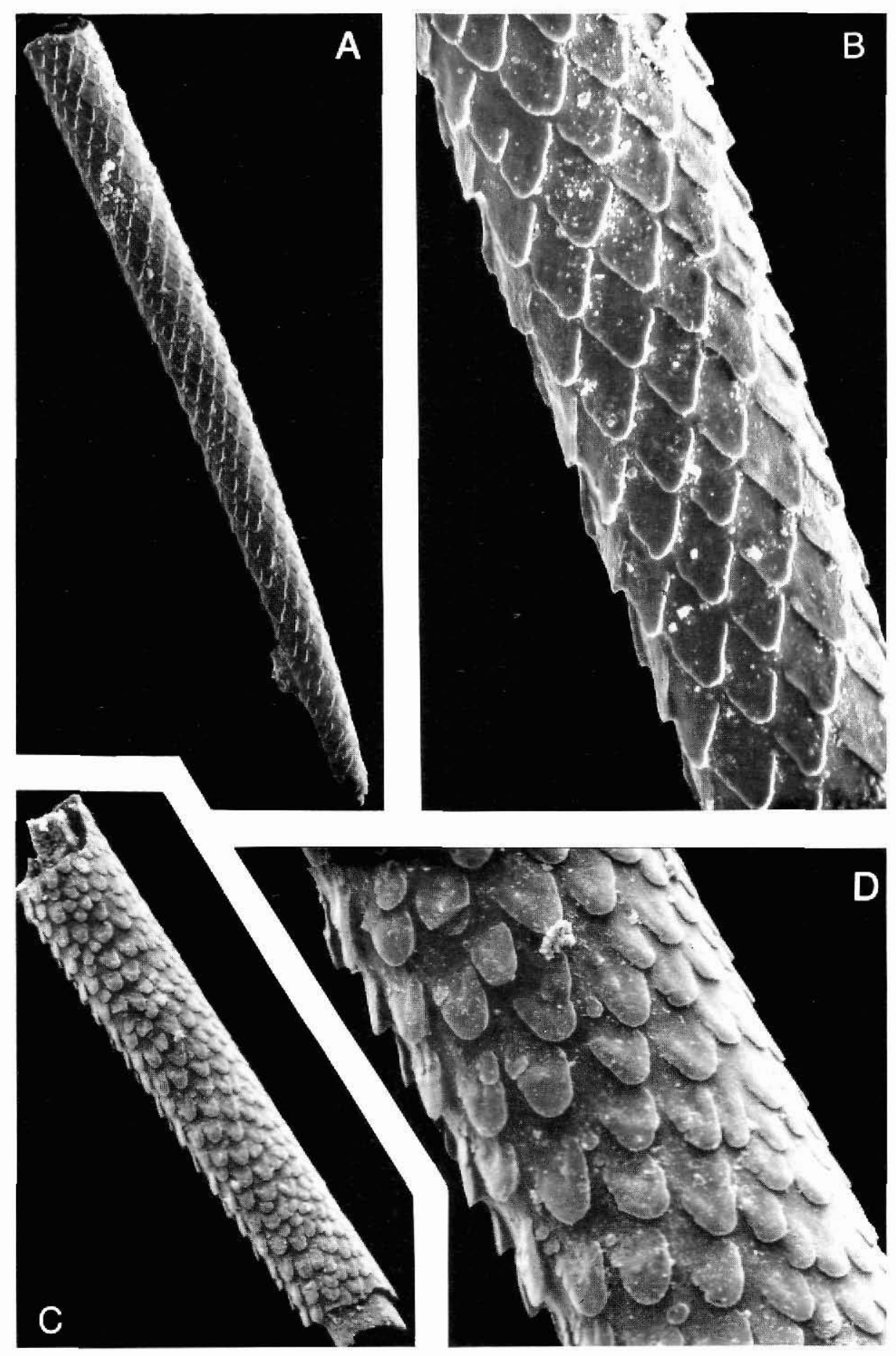

Fig. 2. Mongolitubulus squamifer Missarzhevsky, 1977. Henson Gletscher Formation, southern Freuchen Land. Bonnia-Olenellus Zone, Early Cambrian. A, B, MGUH 18.288 from GGU sample 301351 , slightly curved tube broken at both extremities, $\times 100$ and $\times 400$ respectively. C, D, MGUH 18.289 from GGU sample 301351 , broken at both extremities, $\times 60$ and $\times 200$, respectively. 
seen in fig. 2C, D, with the more ovoid scale-like elements being much less regularly arranged. Smaller elements are interspersed with larger ones in both the specimen from Kazkhstan and the Greenland example and the near perfect squamate pattern seen in fig. $2 \mathrm{~A}, \mathrm{~B}$ is not achieved. However, even in this more perfect pattern, small irregularities are discernible (fig. 2B, upper left).

Missarzhevsky \& Mambetov (1981) commented that the variation in ornamentation between the two small samples from Mongolia (4 specimens) and Maly Karatau (10 specimens) might reflect geographic separation. The large sample from Greenland preserves a spectrum of patterns of ornamentation encompassing both forms.

\section{Associated faunas}

Missarzhevsky \& Mambetov (1981, figs 3, 5) recorded M. squamifer from Koksu and Ushbas in Kazakhstan. At Koksu, M. squamifer occurs together with Redlichia, numerous species of Kootenia and Cheiruroides, the hyolith Burithes elongatus, and new species of Purella, Gaparella, Igorella, Amphigeisina and Koksuja. Lenastella and Chancelloria are also reported. At Ushbas, Kootenia and Cheiruroides are not present, but a more diverse fauna of hyoliths and problematica is reported.

A preliminary summary of the trilobite faunas of the Henson Gletscher Formation in Freuchen Land was given by Blaker (1986). Trilobites associated with $M$. squamifer in GGU sample 301351 are mainly dorypygids referred to Ogygopsis and Kootenia but other specimens are referred to Cheiruroides. Species of Ogygopsis dominate many samples from the Henson Gletscher Formation; specimens from GGU sample 301351 have been identified as Ogygopsis antiqua Palmer, 1968.

Two species of Kootenia are recognised in GGU sample 301351; despite the existence of almost 150 species ascribed to this genus, both these species have unique character combinations that do not allow positive assignment to any previously described species. One of the two species from GGU sample 301351 has 5 pairs of pygidial border spines, yet differs consistently in a combination of ornamentation, number and morphology of axial rings, and the number of pleural furrows from each of the 19 other species with the same number of pairs of pygidial spines. The other species has 3 pairs of border spines and appears to be close in morphology to Kootenia longa Ju, 1983 (a junior homonym of $K$. longa Repina, 1964) from the Lower Cambrian of Zhejiang, China.

Non-trilobite faunas of the Henson Gletscher are as yet little studied but, in addition to Mongolitubulus squamifer, acetic acid residues of GGU sample 301351 have yielded Yochelcionella, Allonia, Lenastella, Olivooides(?), Hyolithellus, Protohertzina cultrata Missarzhevsky, 1977 and possibly Gapparodus bisulcata Müller, 1959; Missarzhevsky, 1977. According to Missarzhevsky \& Mambetov (1981, pp. 61-63), Protohertzina cultrata occurs together with Monogolitubulus squamifer at Ushbas in Maly Karatau, together with species of most of the genera named above, and also in the Sanashtykgol Horizon in Mongolia.

\section{Age of Mongolitubulus}

Missarzhevsky (1977) considered Mongolitubulus to be derived from strata of middle late Early Cambrian age (Lenian) in Mongolia. Missarzhevsky \& Mambetov (1981) suggested a slightly older, late Atdabanian, age for the occurrence of $M$. squamifer in both 
Kazakhstan and Mongolia. Mongolitubulus was considered to occur in a zone of Rhombocorniculum cancellatum in Kazakhstan. They noted that the holotype of $M$. squamifer was derived from the Sanashtykgol Horizon in Mongolia which Shergold \& Brasier (1986), in a recent summary article, dated as Lenian.

Missarzhevsky (1982) proposed a series of 12 zones extending from the upper boundary of the Vendian (late Precambrian) through the Manykayan, Tommotian and Atdabanian Stages into the Botomian (= Lenian). Mongolitubulus, which was considered to be a protocondont by Missarzhevsky (1982), characterised zone XII. The boundary between the Atdabanian and Botomian was placed at the base of zone XII. Rhombocorniculum cancellatum, which was reported to occur in zones X and XI of Atdabanian age, and Mongolitubulus were not considered to have overlapping ranges (Missarzhevsky, 1982, Table 3) although Brasier (1986, fig. 8) considered $R$. cancellatum to extend into the Botomian zone XII.

Missarzhevsky (in Rozanov \& Sokolov, 1984) abandoned use of a Rhombocorniculum cancellatum zone in Kazakhstan, recognising a Microcornus parvulus - Adyshevitheca zone. He considered this latter zone, which is stated to contain Mongolitubulus, to be of Botomian age. Thus, despite earlier opinions that Mongolitubulus was of late Atdabanian age (Missarzhevsky \& Mambetov, 1981), it now appears that a younger, Botomian, age is preferred, as originally suggested by Missarzhevsky (1977) and reiterated by Missarzhevsky (1982).

Mongolitubulus squamifer from Greenland occurs in strata assigned to the zone of Bonnia-Olenellus, considered equivalent to the Botomian and subsequent Toyonian Stages of the Soviet Union Early Cambrian (e.g., Rozanov \& Sokolov, 1984, p. 167).

\section{Early Cambrian palaeogeography}

Mongolitubulus is currently known from Greenland, Mongolia, Kazakhstan and Antarctica. This widely dispersed present-day distribution and the apparent similarity of small shelly faunas between this as yet little-studied part of the Henson Gletscher Formation in North Greenland and the Geress sub-unit in the Kazakhstan sequence are of interest with regard to the reconstruction of Early Cambrian continents recently presented by Parrish $e t$ al. (1986, fig. 22.1). In this, North Greenland is placed on the palaeoequator at the extreme eastern margin of the Laurentian continent. Siberia, the nearest continent to Laurentia, is placed immediately to the east of Greenland, although Mongolia is located at the southern end of this Siberian continent at a similar palaeolatitude to southern Greenland. Kazakhstan, envisaged as an "agglomeration of island arcs and older island arc terrains" (Parrish $e t$ al., 1986, p. 281), forms a separate continent just east of Siberia, located slightly south of the palaeoequator. Antarctica is placed on the palaeoequator at the extreme eastern margin of Gondwana, thus forming the landmass lying west of Laurentia. Incidentally, Parrish et al. (1986) seemed to regard northern Greenland as mainly land during the Cambrian (see particularly their figs 22.4 and 22.5 ). Northern Greenland preserves extensive and richly fossiliferous Lower, Middle and Upper Cambrian sequences representing the eastern continuation of the Franklinian Basin of Arctic Canada (Peel, 1982).

Acknowledgements. Stereoscan facilities were provided by the Laboratory for Electron Microscopy, Geological Central Institute, University of Copenhagen. M. R. B. acknowledges the support of N.E.R.C. Research Studentship GT4/84/GS/37. P. D. Lane is thanked for comments concerning the manuscript. 


\section{References}

Blaker, M. R. 1986: Notes on the trilobite faunas of the Henson Gletscher Formation (Lower and Middle Cambrian) of central North Greenland. Rapp. Grønlands Geol. Unders. 132, 65-73.

Brasier, M. D. 1986: The succession of small shelly fossils (especially conoidal microfossils) from English Precambrian-Cambrian boundary beds. Geol. Mag. 123, 237-256.

Gazdzicki, A. \& Wrona, R. 1986: Polskie badania paleontologiczne w Antarktyce Zachodniej (1986). Przeglad Geologiczny 34,(11), 609-617 [in Polish with English and Russian summaries].

Missarzhevsky, V. V. 1977: [Conodonts (?) and Cambrian phosphatic problematics from Mongolia and Siberia]. Bespozvonochnye Paleozoya Mongolii. Trudy Sovmestaya Sovetsko-Mongolskaya Paleontologicheskaya Ekspeditsiya, 10-19. Moscow: Nauka [in Russian].

Missarzhevsky, V. V. 1982: [Subdivision and correlation of the Precambrian-Cambrian boundary using some groups of the oldest skeletal organisms]. Byul. Moskov. Obschest. Ispytat. Prirod. Otd. Geol. 57, 52-67 [in Russian].

Missarzhevsky, V. V. \& Mambetov, A. M. 1981: [Stratigraphy and fauna of Cambrian and Precambrian boundary beds of Maly Karatau]. Akad. Nauk SSSR Trudy Ordena Tryd. Krasn. Zham. Geol. Inst. 326, 92 pp. [in Russian].

Parrish, J. T., Ziegler, A. M., Scotese, C. R., Humphreville, R. G. \& Kirschvink, J. L. 1986: Proterozoic and Cambrian phosphorites - speciallist studies: Early Cambrian palaeogeography, palaeoceanography and phosphorites. In Cook, P. J. \& Shergold, J. H. (edit.) Phosphate deposits of the world 1. Proterozoic and Cambrian phosphorites, 280-294. Cambridge Univ. Press.

Peel, J. S. 1982: The Lower Paleozoic of Greenland. Mem. Can. Soc. Petrol. Geol. 8, 309-330.

Rozanov, A. Yu \& Sokolov, B. S. (edit.) 1984: [Lower Cambrian stage subdivision. Stratigraphy]. Akad. Nauk SSSR Otdel. Geol. Geofiz. Geokhim., 184 pp. Moscow: Nauka [in Russian].

Shergold, J. H. \& Brasier, M. D. 1986: Proterozoic and Cambrian phosphorites - speciallist studies: biochronology of Proterozoic and Cambrian phosphorites. In Cook, P. J. \& Shergold, J. H. (edit.) Phosphate deposits of the world 1. Proterozoic and Cambrian phosphorites, 295-326. Cambridge Univ. Press. 